\title{
Nutrition, Cities and Territorial Planning: Jump Starting the SDGs?
}

\section{Florence Egal}

Food Security and Nutrition expert, Italy

"Corresponding author: Florence Egal, Retired Senior Officer, Food Security, Nutrition expert, Italy,

E-mail: florence.egal@gmail.com

Citation: Egal, F. Nutrition, Cities and Territorial Planning: Jump Starting the SDGs? (2016) J Environ Health Sci 2(4): 1-2

DOI: $10.15436 / 2378-6841.16 .1087$

\section{Introduction}

At the 2014 second International Conference on Nutrition in Rome ${ }^{[1]}$, world leaders agreed that the eradication of malnutrition and the prevention of NCDs would require the promotion of diversified, balanced and healthy diets and therefore "sustainable, equitable, accessible in all cases, and resilient and diverse food systems" (including social protection for the progressive realization of the right to adequate food). They committed to establishing national policies aimed at addressing all forms of malnutrition and transforming food systems to make nutritious diets available to all.

On 4/4/2016, the UN General Assembly declared the UN Decade on Nutrition ${ }^{[2]}$ led by FAO and WHO, it aims to prevent all forms of malnutrition, recognizes the role of nutrition in achieving the SDGs" and endorses the Rome Declaration on Nutrition and Framework for Action.

At the same time, the $13^{\text {th }}$ International Conference on Urban Health in San Francisco launched the WHO - UN-Habitat Global Report on Urban Health - Equitable, Healthier Cities for Sustainable development ${ }^{[3]}$ which encouraged cities to endorse their leadership position, exploit the urban advantage, promote sustainable food systems for food security and initiate local action for improvements in healthy eating behaviour.

As we head towards the $3^{\text {rd }}$ UN Conference on Housing and Sustainable Urban Development in October in Quito[3], sustainable food systems are high on the international agen-

1 http://www.fao.org/about/meetings/icn2/en/?\%A2\%06

$2 \mathrm{http} / / / \mathrm{www}$. who.int/nutrition/GA decade action/en/

3 https://www.habitat3.org/the-new-urban-agenda/
Received date: September 2, 2016

Accepted date: November 10, 2016

Published date: November 17, 2016

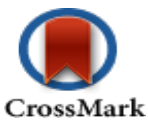

da. There is increasing awareness, in particular in the health and food and agriculture sectors, that unless we move beyond economic development and embark on a broader reflection on how to manage natural resources and ensure local livelihoods, we will not be able to address malnutrition and prevent NCDs, alleviate poverty, deal with urbanization, manage crisis, mitigate climate change or protect biodiversity.

Present food and agriculture policies - focussed on value chains and biased towards international trade - are supply-driven and have resulted in an increased disconnect between production and consumption. The concept of sustainable diets - diets which are nutritionally adequate, safe and healthy, but also culturally acceptable, accessible, economically fair and affordable and have a low environmental impact (respectful of biodiversity and ecosystems) - can provide the basis for a demand driven approach bringing together the social, economic and environmental dimensions of sustainable development and contribute to the reorientation and rationalization of local food systems.

But how can such complex approaches are operationalized? National policies, programmes and research - and related institutions - have classically developed within technical sectors and are based on methodologies which give limited space to social or environmental dimensions. Most countries present a diversity of eco-systems and socio-cultural contexts. Sustainable approaches should therefore logically be local-specific and developed at sub-national level.

Food consumption in cities is a major determinant of the health of the urban population but it also influences rural 
diets and determines farming systems, which in turn affect diets and health in urban areas. Municipalities are increasingly concerned by the rising costs generated by NCDs. The Urban Food Policy Pact initiative, launched by the Mayor of Milan on occasion of the 2015 Expo Feeding the Planet, Energy for Life, has brought more than 120 cities worldwide ${ }^{[4]}$ (among which Barcelona, Bilbao, Cordoba, Madrid, Valencia) to commit to sustainable food systems and inter-city collaboration. The pact, built upon city experiences, explicitly promotes sustainable diets and prevention of non-communicable diseases associated with poor diets and obesity, giving specific attention where appropriate to reducing intake of sugar, salt, transfats, meat and dairy products and increasing consumption of fruits and vegetables and non-processed foods. It advocates for a comprehensive pro-poor approach to address the socio-economic determinants of health.

The Milan Urban Food Policy Pact, officially presented to the UN Secretary General on World Food Day in the wake of the UN Sustainable Development Summit ${ }^{[5]}$, draws upon city-level experience and relevant commitments, and in particular the ICN2 Rome Declaration on Nutrition and Framework for Action. It is illustrated by 50 good practices provided by partner cities (including Bilbao on Fair Trade week, and Barcelona, A net of Modern Markets). An awards programme will be launched at the second Mayor's summit hosted in October in Rome with a view to enhance exchange of experiences and knowledge management.

Governance is a key to the success of the Pact. In order to move towards more sustainable, healthy and equitable food systems which balance urban and rural interests, the mayors have committed to facilitate collaboration across city departments and to seek alignment of policies and programmes, both at local level and with relevant national and global policies and processes. They have agreed in enhancing stakeholder participation at city and territorial level and reviewing and harmonizing municipal regulations.

The Pact aims to ensure sustainable diets and good nutrition, as well as social and economic equity, in particular through social protection programmes and social and solidarity economy. It revisits food production and food supply and distribution with specific attention to sustainable natural resources management, rural-urban linkages and decent employment and it promotes prevention and management of food waste.

It therefore provides an opportunity to concretely rethink food and agriculture development within a broad framework, moving beyond commodities and value chains to food systems and diets; shifting from supply-driven and mass distribution-led approaches to demand-driven and consumer-led policies: and from a focus on international trade and free circulation of foods to the promotion of local food systems, which should lead to a revision of the legislative and regulatory context for better articulation of global and local food systems.
There is increased awareness that malnutrition, poverty and environmental degradation in the context of climate change are related to the food we eat and the way it is produced, processed and distributed; and that sustainable diets are the foundation of sustainable food systems. The Milan Urban Food Policy initiative provides all actors with an opportunity to contribute knowledge and experience and participate in joint planning. The active involvement of the health sector. In this regard, close collaboration with the food and agriculture sector will be essential for effective advocacy and good planning. Until fairly recently, people's feeding practices, in particular in rural areas, were closely related to the ecosystem they lived in. Traditional diets reflected local lifestyles, shaped local economies and landscapes and often remain an essential dimension of people's culture. They classically made sustainable use of local natural resources relied on seasonal combination of plant and animal foods, whether cultivated/raised or collected/hunted from the wild, which were processed at household or local level, thereby allowing extended consumption and trade and providing jobs and income. Farming systems were risk-adverse and together with traditional solidarity networks allowed people to cope with recurrent hazards. In most cases the promotion of traditional diets provides an opportunity for much-needed inter sectoral partnerships (in particular health, agriculture and environment).

Revisiting and revitalizing traditional diets and related food systems should therefore help mayors to reorient and complement existing food systems with a view to improve health, social equity and environmental sustainability. Cities with similar ecological and cultural backgrounds would benefit from sharing knowledge, experience and lessons learnt.

While cities are increasingly aware of their potential role and responsibilities in addressing malnutrition in all its forms (under nutrition and overweight/obesity), they face major institutional challenges: sectoral silos, tensions with regional or central authorities, limited people's participation, disconnect with academia and civil society. Successful experiences - and failures - and materials are not being documented, reviewed and shared. At a time when most of the world's population lives in cities, development assistance modalities should be revisited to explicitly acknowledge the role and comparative advantage of cities and local governments in promoting sustainable development, generate practice-based evidence, and provide appropriate support for enhanced synergy and use of resources. Local academic and research institutions can provide technical assistance to authorities and other actors in particular for assessment, monitoring and evaluation, review and documentation of local experience and practices, and training of both institutions and public.

Local food policies for sustainable food systems and nutrition touch on most if not all SDGs. Cities and their territories offer a concrete opportunity for jumpstarting the 2030 Agenda for Sustainable Development.

4 http://www.milanurbanfoodpolicypact.org

5 https://sustainabledevelopment.un.org/post2015/summit

Ommega Online Publishers

Journal Title: Journal of Environment and Health Science (JEHS)

Journal Short Name: J Environ Health Sci
Journal ISSN: 2378-6841

E-mail: environmentalscience@ommegaonline.org

Website: www.ommegaonline.org 